\title{
Macroeconomic Variables and the Performance of the Nigerian Capital Market
}

\author{
Harcourt, Edwin Ejikeme \\ Department of Finance \& Banking, Faculty of Management Sciences \\ University of Port Harcourt
}

\begin{abstract}
This study was set out to empirically investigate the impact of four selected macroeconomic variables which includes inflation, prime lending rate, foreign exchange rate and real gross domestic product on the performance of the Nigerian capital market. The NSE all-share index and market capitalization were used as proxies for capital market performance. Quarterly time series data covering the period between 1986 and 2009 are used. The analysis starts with examining stochastic characteristics of each time series by testing their stationarity using Augmented Dickey Fuller (ADF) test. The findings show that only inflation is stationary at level, while the other time series are stationary at either first or second difference. The Johansen cointegration procedure indicates that the variables are co-integrated. The likelihood ratio revealed two cointegrating equations in both cases. From the error correction model, the following interesting findings are made; real gross domestic product has positive impact on the performance of the capital market in Nigeria. The study shows that the high rising inflation rate in Nigeria impacts negatively on the performance of the stock market. But while its negative impact is significant at $5 \%$ on all-share index, it remained insignificant on market capitalization. Also foreign exchange rate of naira to one US dollar does not have any significant impact on capital market performance and prime lending rate has a negative impact on capital market performance. Further findings show that previous stock market performance has a positive impact on the present performance. Lastly, the findings are further reinforced by the presence of a long-term equilibrium relationship, as evidenced by the co-integration and stability of the model. The coefficients of the error correction terms are negative, significant and less than one, which justifies the use of an ECM specification of the model. The study recommended that government should formulate active and flexible monetary policies to check unfavorable developments in the market as they arise and the Federal government should continue to pay particular attention to price stability as one of the key macroeconomic policy objectives in order to curb inflation.
\end{abstract}

Keywords: Macroeconomic Variables, Inflation, Gross Domestic Product, Capital Market, Interest Rate, Foreign Exchange Rate

\section{INTRODUCTION}

Capital markets play an important role in the financial sector of an economy. An efficient capital market can promote economic growth and prospect by stabilizing the financial sector and providing an important channel for attracting domestic and foreign capital. Capital market efficiency means that the unanticipated portion of the return on a security is unpredictable and over a sufficient number of observations, it does not differ systematically from zero. The unanticipated portion is the actual return less what was expected based on some fundamental analysis.

An efficient capital market is one in which security prices adjust rapidly to the arrival of new information and, therefore, the current prices of securities reflect all information about the security (Reilly and Brown, 1999). What this means in simple terms is that no investor should be able to employ readily available information in order to predict stock price movements quickly enough so as to make a profit through trading shares. An efficient capital market can promote economic growth and prospect by stabilizing the financial sector and providing an important channel for attracting domestic and foreign capital.

Fama (1970) defined market efficiency in the forms of weak, semi-strong, or strong. The weak-form of market efficiency means the unanticipated return is not correlated with previous unanticipated returns, thus the market has no memory and knowledge of past returns, and they have no bearing on determining future returns. Semistrong-form market efficiency means market returns are not 
correlated with any publicly available information. And lastly, with the strong-form of market efficiency, the unanticipated return is not correlated with any information, be it public or insider, since all available information is already being reflected in the present returns. Efficient Market Hypothesis $(\mathrm{EMH})$ has important implications for policy-makers and stockbrokers alike.

Policy makers, for example, should feel free to conduct national macroeconomic policies without the fear of influencing capital formation and stock trade process. The causal relations and dynamic interactions among macroeconomic variables and stock prices are important in the formulation of the nation's macroeconomic policy. As for the effect of macroeconomic variables such as money supply and interest rate on stock prices, the efficient market hypothesis suggests that competition among the profit maximizing investors in an efficient market will ensure that all the relevant information currently known about changes in macroeconomic variables are fully reflected in current stock prices, so that investors will not be able to earn abnormal profit through prediction of future stock market movement (Chong and Koh 2003).

In contradiction to the conclusions drawn by the EMH, evidence that key macroeconomic variables help predict the time series of stock returns has accumulated for nearly 3 decades. The assault on the conclusions drawn from the EMH includes early studies by Nelson (1976), and Jaffe and Mandelker (1976), all affirming that macroeconomic variables influence stock returns.

Concentrating principally on the US stock exchanges, such early studies attempted to capture the effects of economic forces in a theoretical framework based on the Arbitrage Pricing Theory (APT) developed by Ross (1976). The APT essentially seeks to measure the risk premium attached to various factors that influence the returns on assets, whether they are significant, and whether they are "priced" into stock market returns. Accordingly, Chen, Roll and Ross (1986), having first illustrated that economic forces affect discount rates, the ability of firms to generate cash flows, and future dividend payouts, provided the basis for the belief that a long-term equilibrium existed between stock prices and macroeconomic variables.

Stock market is a critical cog that aids the transfer of funds for economic growth. Broadly speaking stock exchanges are expected to accelerate economic growth by increasing liquidity of financial assets and making global risk diversification easier for investors promoting wiser investment decisions. In principle, a well-functioning stock market may help the economic growth and development process in an economy through growth of savings, efficient allocation of investment resources and attracting foreign portfolio investment.

Stock Markets in emerging countries are generally characterized as unstable and shallow resulting in an oversensitivity of stock returns to macroeconomic developments. These two features lead to the fact that macroeconomic factors still have the potential to play a very important role on stock market performance. The Nigeria Stock Exchange is no exception to this context. Therefore, it is not surprising to see many studies dedicated to analyzing the impact of macroeconomic factors on stock returns in the Nigerian economy.

\section{OBJECTIVES OF THE STUdY}

The main objective of this study is to investigate the relationship between stock market returns and macroeconomic variables. But specifically, the study intends:

- To analyze the effect of inflation on all share index and market capitalization as proxies for the performance of the Nigerian capital market.

- To test the effect of lending rate on all share index and market capitalization.

- To investigate the relationship between foreign exchange rate and both all share index and market capitalization.

- To assess the significance of real gross domestic product on all share index and market capitalization.

- To draw conclusion and make policy recommendations based on the findings of the study.

\section{LITERATURE REVIEW AND THEORETICAL FRAMEWORK}

This section looks at relevant literature, theoretical framework and empirical studies surrounding the relationship between macroeconomic variables and the stock market returns. 


\subsection{Theoretical Framework}

\subsubsection{Financial Economic Theory}

One way of linking macroeconomic variables and stock market returns is through the Arbitrage Pricing Theory (APT) (Ross, 1976), where multiple risk factors can explain asset returns. APT holds that the expected return of financial asset can be modeled as a linear function of various macroeconomic factors or theoretical market indices, where sensitivity to change in each factor is represented by a factor specific beta coefficient. It is often viewed as an alternative to the capital asset pricing model (CAPM), since it has more flexible assumptions. Whereas the CAPM requires the market's expected return, the APT uses the risky assets expected return and the risk premium of a number of macroeconomic factors.

The basis of APT is the idea that the price of a security is driven by a number of factors. These factors could be macroeconomic factors or company specific factors. APT does not rely on measuring the performance of the market. Instead it directly relates the price of the security to the fundamental factors driving it. The problem with APT is that the theory itself provides no indication of what these factors are, so they need to be determined empirically.

While early empirical studies on APT focused on individual security returns, it may also be used in an aggregate stock market framework, where a change in a given macroeconomic variable could be seen as reflecting a change in an underlying systemic risk factor influencing future returns. Most of the empirical studies on APT, linking the state of the macro economy to the stock market returns, are characterized by modeling a short run relationship between macroeconomic variables and the stock price in terms of first difference, assuming trend stationarity.

An alternative, but not inconsistent approach is the discounted cash flow or Present Value Model (PVM). This model relates the stock price to future expected cash flows and the discount rate of these cash flows. Again, all macroeconomic factors that influence future expected cash flow or the discount rate by which these cash flows are discounted should have an influence on the stock price. The advantage of the PVM model is that it can be used to focus on the long-run relationship between the stock market and macroeconomic variables. Campbell and Shiller (1988) the relationship between stock prices, earnings and expected dividends. They find that a long term moving average of earnings estimates predict dividends and the ratio of this earnings variable to current stock price is powerful in predicting stock returns over several years. They conclude that these factors make stock prices and returns much too volatile to accord with a simple present value model.

\subsubsection{The Fundamental View}

This theory posits that, at any point in time, an individual security has an intrinsic or true value, which is the present value of the future receipts accruing to the security holder. The theory also holds that, the intrinsic value of the security depends on some essential factors affecting the company, the industry and the economy. The principal discussion variables in fundamental analysis are earnings and dividends. Earnings depend on the relationship between expected sales and costs, which are affected by several factors, internal to the firm's operating environment. Therefore, the fundamentalists forecast stock prices on the basis of economic industry and company statistics (Pratten, 1993).

Fundamental analysis also attempts to identify factors influencing or likely to influence share prices, that is, the market reaction to information about the economy, industry and company. In assessing the company, great reliance is placed on its published financial statements in addition to assessing the quality of management. With all information, the investor arrives at an estimate of the intrinsic or true value of the company, since other investors may likely arrive at the same conclusion. Using the same information, the intrinsic value is likely to be a price towards which market price moves. Thus, to calculate the intrinsic value is to predict the market price. However, if fundamental analysis is used as a guide for investment decision, the buy and sell decision will be based on the discrepancy between intrinsic value and market price. If intrinsic value is greater than market prices, the investor should buy and sell, if the market price is greater than the intrinsic value. The amount of the discrepancy and the speed with which the market price approaches an intrinsic value may be regarded as indications of the degree of perfection in the market. There will be no discrepancies between intrinsic and market values of securities, if the market is at least near perfect. Hence, there will be a little or no opportunity 
for an investor to beat the market and make abnormal or substantial profit. Furthermore, if profit from fundamental analysis is small, there will be little justification for incurring costs of undertaking fundamental analysis (Pratten, 1993).

\subsubsection{The Technical Theory}

The technical school on the other hand, opposes the fundamentalists' agreements. According to Foley (1991), technical analysis, also referred to as Chartism, takes the view that in attempting to predict the future course of share prices it is useful to focus on the past behavior of share prices. Chartists argue that share prices move in trends and patterns, which periodically repeat themselves so that the key to making gains is to recognize these patterns before others. According to technical analysis, it really does not matter in which industry or market the company operates, the use of chart is sufficient to detect the likely movement in the prices of its shares. According to Smith (1990), technical analysts engage themselves in studying changes in market prices, the volume of trading and investors' attitude.

Technical analysis is faulty in the sense that it does not have any basis, nor does it want to investigate to know why a particular share price is predicted to rise or fall. All that is important is that the movement is indicative of a rise or a fall (Pratten, 1993).

\section{EMPIRICAL REVIEW}

The issue of relationship between macroeconomic variables and share returns over the years have stemmed up controversies among researchers based on the different findings. Theoretically, macroeconomic variables are expected to affect returns on equities. But over the years, the observed pattern of influence of macroeconomic variables (in signs and magnitude) on share returns varies from one study to another in different capital markets.

A brief overview of studies using macroeconomic factor models is presented in this section. The findings of the literatures suggest that there is a significant linkage between macroeconomic indicators and stock returns in the countries reviewed. The review is classified into three; developed, developing and the Nigerian studies. Flannery and Protopapadakis (2002) re-evaluate the effect of some macroeconomic series on US stock. Among these series six macroeconomic variables, namely, balance of trade, housing, employment, consumer price index, M1 and producer price index seem to affect stock returns. On the other hand, two popular measures of aggregate economic activity (real GNP and industrial production) do not appear to be related with stock returns.

Ibrahim and Aziz (2003) investigate the relationship between stock prices and industrial production, money supply, consumer price index, and exchange rate in Malaysia. Stock prices are found to share positive long-term relationships with industrial production and CPI. On the contrary, they found out that stock prices have a negative association with money supply and exchange rate.

Serkan (2008) investigates the role of macroeconomic factors in explaining Turkish stock returns. He employed macroeconomic factor model from the period of July 1997 to June 2005. The macroeconomic variables considered are growth rate of industrial production index, change in consumer price index, growth rate of narrowly defined money supply, change in exchange rate, interest rate, growth rate of international crude oil prices and return on MSCI World Equity index. He found that exchange rate, interest rate and world market return seem to affect all of the portfolio returns, while inflation rate is significant for only three of twelve portfolios. Also, industrial production, money supply and oil prices do not appear to have significant effect on stock returns in Turkey.

Adam and Tweneboah (2008) examined the impact of macroeconomic variables on stock prices in Ghana using quarterly data from 1991 to 2007. They examined both the long-run and short-run dynamic relationships between the stock market index and economic variables namely, inward foreign direct investment, Treasury bill rate, consumer price index, average oil prices and exchange rates using co integration test and Vector Error Correction Model (VECM). They found that there is cointegration between macroeconomic variables and stock prices in Ghana indicating long-term relationship. The VECM analysis shows that the lagged values of interest rate and inflation have significant influence on the stock market. Also, the inward foreign direct investments, oil prices and the exchange rate demonstrate weak influence on price changes. 
Amadi, Onyema and Odubo (2002) employed multiple regression analysis to estimate the functional relationship between money supply, inflation, interest rate, exchange rate and stock prices in Nigeria. Their study revealed that the relationship between stock prices and macroeconomic variables are consistent with theoretical postulations and empirical findings in some countries. Their findings also revealed that the relationship between stock prices and inflation does not agree with some other works done outside Nigeria.

Nwokoma (2002) attempted to establish a long-run relationship between the stock market and some macroeconomic indicators. His result shows that only industrial production and level of interest rates, as represented by the three months' commercial bank deposit rate have a long-run relationship with the stock market. He also found that the Nigerian market responds more to its past prices than changes in the macroeconomic variables in the short-run.

Ologunde, Elumilade and Asaolu (2006) examined the relationship between stock market capitalization rate and interest rate. They found that the prevailing interest rate exerts positive influence on stock market capitalization rate. They also found that government development stock rate exerts negative influence on stock market capitalization rate and prevailing interest rate exerts negative influence on government development stock rate.

Maku and Atanda (2009) used error correction model to examine the relationship between stock market performance and five macroeconomic variables which include - consumer price index, treasury bill rate, broad money supply, real output and exchange rate. They found that the NSE all share index is consistently determined by exchange rate, broad money supply, consumer price index and real output in both the short-run and long-run. This implies that investors in Nigeria should pay more attention to the significant macroeconomic variables mentioned above in their investment decisions rather than the Treasury bill rate.

\section{RESEARCH METHODOLOGY}

The study adopts the desk survey method. Data were collected from various publications of government agencies. Data so collected were summarized and tabulated prior to analysis. Data were generated basically from the secondary sources. The study made use of quarterly time series data from 1986-2009 sourced from various publications of Central Bank of Nigeria (CBN), Nigerian Stock Exchange (NSE) and National Bureau of Statistics (NBS).

Data obtained from this source include; quarterly lending rates and monthly average of official foreign exchange rate of the Naira vis-à-vis the United States' Dollar. The monthly averages were further adjusted to quarterly averages for the purpose of this study. All these data were obtained from various editions of the CBN statistical bulletins.

The end-of-month data of the NSE all-share index and market capitalization were obtained from various publications of the NSE. The end-of-month data was also adjusted to quarterly averages for the purpose of our study.

\section{Model Specification}

One way of linking macroeconomic variables and stock market returns is through the Arbitrage Pricing Theory (APT) (Ross, 1976), where multiple risk factors can explain asset returns. Based on the concept of Arbitrage Pricing Theory (APT) which explains the relationship between stock returns and macroeconomic variables, our models are specified thus:

$A S I=f(I N F, P L R, F E X, G D P)$

$M K C=f(I N F, P L R, F E X, G D P)$

In order to see whether the above macroeconomic variables could explain the NSE All-Share index and Market Capitalization, equations (I) and (II) above are transformed econometrically as;

$$
\begin{aligned}
& L N A S I_{t}=\beta_{o}+\beta_{1} I N F_{t}+\beta_{2} L N P L R_{t}+\beta_{3} L N F E X_{t}+\beta_{4} L N G D P t+\mu_{t} \\
& L N M K C_{t}=\alpha_{o}+\alpha_{1} I N F_{t}+\alpha_{2} L N P L R_{t}+\alpha_{3} L N F E X_{t}+\alpha_{4} L N G D P_{t}+\varepsilon_{t}
\end{aligned}
$$

Where,

$$
\text { ASI } \quad=\quad \text { NSE All-share index }
$$




$\begin{array}{lll}\text { MKC } & = & \text { Market Capitalization } \\ \text { INF } & = & \text { Inflation } \\ \text { PLR } & = & \text { Prime lending rate } \\ \text { FEX } & = & \text { Foreign exchange rate } \\ \text { GDP } & = & \text { Real gross domestic product } \\ \beta_{0}, \alpha_{0} & = & \text { Constants } \\ \beta_{1-4}, \alpha_{1-4} & = & \text { Coefficients of the variables } \\ \mu_{\mathrm{t}}, \varepsilon_{\mathrm{t}} & = & \text { Stochastic error terms }\end{array}$

All the variables, except inflation, are transformed into natural logs to reduce multicollinearity and assume linearity.

\section{TECHNIQUES OF DATA ANALYSIS}

The study adopts a time series technique. The estimation procedure begins with a unit root test, followed by a test of co-integration, then estimation of an over-parameterized model and finally parsimonious model. All estimations were performed in the econometrics software program EVIEWS.

\section{Data Presentation, Analysis and Discussion of Findings}

In this section, data collected to aid the study is presented, analyzed and interpreted in order to have an informed judgment about the relationship between the selected macroeconomic variables and the performance of the stock market.

The data used in this study covered the period of 1986Q1 - 2009Q4 as shown in appendix I, and were collected from various editions of Central Bank of Nigeria statistical bulletins, Nigeria Stock Exchange and National Bureau of Statistics publications.

\section{DESCRIPTIVE STATISTICS OF THE STUDY VARIABLES}

Various descriptive statistics are calculated from the variables under study in order to describe the basic characteristics of these variables. Table 4.1 presents the descriptive statistics of the data collected. It contains the sample means, medians, maximums, minimums, standard deviations, skewness, kurtosis as well as the Jarque-bera statistics and probabilities (p-values).

Table1. Descriptive statistics of study variables

\begin{tabular}{|l|l|l|l|l|l|l|}
\hline & \multicolumn{1}{|c|}{ ASI } & \multicolumn{1}{c|}{ MKC } & \multicolumn{1}{c|}{ INF } & \multicolumn{1}{c|}{ PLR } & \multicolumn{1}{c|}{ FEX } & \multicolumn{1}{c|}{ GDP } \\
\hline Mean & 11414.22 & 1764088. & 23.11354 & 19.27188 & 63.72708 & 94041.03 \\
\hline Median & 5830.850 & 273000.0 & 13.95000 & 18.94000 & 21.90000 & 76229.15 \\
\hline Maximum & 60953.00 & 13400000 & 87.90000 & 29.80000 & 150.9000 & 210146.9 \\
\hline Minimum & 138.4000 & 6703.110 & -1.900000 & 8.680000 & 1.000000 & 49928.80 \\
\hline Std. Dev. & 14492.87 & 3347457. & 21.42391 & 4.151985 & 55.39230 & 40263.81 \\
\hline Skewness & 1.724086 & 2.237646 & 1.181867 & 0.140178 & 0.231157 & 1.099209 \\
\hline Kurtosis & 5.482412 & 6.893660 & 3.256624 & 3.670663 & 1.217936 & 3.158979 \\
\hline Jarque-Bera & 72.20906 & 140.7553 & 22.61237 & 2.113555 & 13.55794 & 19.43328 \\
\hline Probability & $0.000000^{*}$ & $0.000000^{*}$ & $0.000012^{*}$ & 0.347574 & $0.001137^{*}$ & $0.000060^{*}$ \\
\hline Observatios & 96 & 96 & 96 & 96 & 96 & 96 \\
\hline
\end{tabular}

Note: Asterisk (*) denotes the null of normality was rejected at $1 \%$ significance level.

\section{Source: Compiled by author}

As can be seen from table 1, all the variables are asymmetrical. More precisely, skewness is positive for all the variables. Kurtosis value of all the variables also shows data is not normally distributed because the values of kurtosis are deviated from 3. The Jarque-Bera statistics and p-values reject the normality assumption at $1 \%$ level of significance for all the variables except lending rate. Therefore, the descriptive statistics show that the values are not normally distributed about its mean and variance. In other words, we can say that there is no randomness in the data and therefore, being sensitive to speculation shows a periodic change. This indicates that individual investors can earn considerably higher than normal rate of profit from the Nigerian stock market. This, therefore, raises the issue of inefficiency in the market. 


\section{Unit Root TeSt Results}

In literature, most time series variables are non-stationary and using non-stationary variables in the model might lead to spurious regressions (Granger and Newbold 1977). The first or second differenced terms of most variables will usually be stationary (Ramanathan 1992). In this study, all the variables are tested at levels, first and second differences for stationarity using the Augmented Dickey-Fuller (ADF) test. The result shows all the variables except inflation are non-stationary at level as presented in table 4.2. However, inflation (INF) is stationary at level at 5\% significance level. Furthermore, the result shows that all the variables are stationary at first or second difference. Hence, it can be concluded that all the variables except inflation are integrated of either order one [I(1)] or order two [1(2)].

Table2. Unit root test - augmented dickey fuller test

\begin{tabular}{|l|l|l|l|l|l|}
\hline Variables & Trend & At Level & At $1^{\text {st }}$ Difference & $\begin{array}{l}\text { At } \\
\text { Difference }\end{array}$ & $\begin{array}{l}\text { Order } \\
\text { integration }\end{array}$ \\
\hline LNASI & Without & -1.79 & $-6.54^{*}$ & $-8.40^{*}$ & $\mathrm{I}(1)$ \\
\hline LNMKC & Without & -0.67 & $-3.34^{* *}$ & $-7.06^{*}$ & $\mathrm{I}(2)$ \\
\hline INF & Without & $-3.21^{* *}$ & $-5.60^{*}$ & $-9.07^{*}$ & $\mathrm{I}(0)$ \\
\hline LNPLR & Without & -2.61 & $-4.16^{*}$ & $-6.44^{*}$ & $\mathrm{I}(1)$ \\
\hline LNFEX & With & -2.96 & $-8.63^{*}$ & $-9.01^{*}$ & $\mathrm{I}(1)$ \\
\hline LNGDP & With & -1.21 & $-3.96^{* *}$ & $-9.22^{*}$ & $\mathrm{I}(2)$ \\
\hline
\end{tabular}

Source: Computed by the author

*Significant at $1 \%$, **Significant at $5 \%$

Critical value with trend: $\quad 1 \% \quad-4.06$

$5 \% \quad-3.46$

Critical value without trend: $\quad 1 \% \quad-3.50$

$5 \% \quad-2.89$

\section{Co-InTEgration TeSt Results}

Given that all the variables, except one, are integrated of either order one or order two, co-integration test was carried out to establish whether the variables, though individually non-stationary, could be co-integrated as a group and also to establish the existence of a long-run relationship among them. The Johansen procedure is used to achieve this.

Table3. Hypothesis one with ASI as the dependent variable

\begin{tabular}{|l|l|l|l|l|l|}
\hline Eigenvalues & 0.305 & 0.225 & 0.154 & 0.106 & 0.075 \\
\hline Hypothesis & $\mathrm{r}=0$ & $\mathrm{r}=1$ & $\mathrm{r}=2$ & $\mathrm{r}=3$ & $\mathrm{r}=4$ \\
\hline Trace test & $90.827^{*}$ & $56.942^{*}$ & 33.206 & 17.675 & 7.278 \\
\hline Critical value at 5\% & 76.973 & 54.079 & 35.193 & 20.262 & 9.165 \\
\hline
\end{tabular}

Source: Computed by the author

*Indicates rejection of the likelihood ratio tests at 5\% significant level.

Note: None of the deterministic variable is restricted to the co-integration space and trace test is adjusted for degrees of freedom. The critical values are taken from MacKinnon-Haug-Michelis (1999)

Table4.Hypothesis two with MKC as the dependent variable

\begin{tabular}{|l|l|l|l|l|l|}
\hline Eigenvalues & 0.329 & 0.263 & 0.180 & 0.071 & 0.031 \\
\hline Hypothesis & $\mathrm{r}=0$ & $\mathrm{r}=1$ & $\mathrm{r}=2$ & $\mathrm{r}=3$ & $\mathrm{r}=4$ \\
\hline Trace test & $93.594^{*}$ & $56.550^{*}$ & 28.225 & 9.773 & 2.973 \\
\hline Critical value at 5\% & 76.973 & 54.079 & 35.193 & 20.262 & 9.165 \\
\hline
\end{tabular}

Source: Computed by the author

*Indicates rejection of the likelihood ratio tests at $5 \%$ significant level.

Note: None of the deterministic variable is restricted to the co-integration space and trace test is adjusted for degrees of freedom. The critical values are taken from MacKinnon-Haug-Michelis (1999)

Tables 3 and 4 report the estimates of Johansen procedure and standard statistics. This study used the degrees of freedom adjusted version of trace statistic to determine the number of co-integrating vectors since with the existence of small samples with too many variables or lag the procedure tends 


\section{Harcourt \& Edwin Ejikeme}

to overestimate the number of co-integrating vectors (Civcir, 2003). The tests statistics strongly rejects the null hypothesis in favour of two co-integration relationship at 5\% significant level.

\section{TEST OF HYPOTHESES}

Ho: There is no significant relationship between the selected macroeconomic variables and the all share index.

Table5. Parsimonious error correction result

\begin{tabular}{|c|c|c|c|c|}
\hline \multicolumn{5}{|c|}{ Dependent Variable: D(LNASI) } \\
\hline \multicolumn{5}{|c|}{ Method: Least Squares } \\
\hline \multicolumn{5}{|c|}{ Date: 07/13/12 Time: 23:09 } \\
\hline \multicolumn{5}{|c|}{ Sample(adjusted): 1987:2 2009:4 } \\
\hline \multicolumn{5}{|c|}{ Included observations: 91 after adjusting endpoints } \\
\hline Variable & Coefficient & Std. Error & t-Statistic & Prob. \\
\hline $\mathrm{C}$ & 0.052078 & 0.013756 & 3.785794 & 0.0003 \\
\hline D(LNASI(-1)) & $0.465984 *$ & 0.094547 & 4.928610 & 0.0000 \\
\hline D(LNGDP(-1)) & $0.621146^{*}$ & 0.115648 & 2.880366 & 0.0051 \\
\hline D(LNPLR(-2)) & $-1.544743 *$ & 0.531499 & -2.906390 & 0.0047 \\
\hline $\mathrm{D}(\operatorname{LNFEX}(-2))$ & -0.127901 & 0.073500 & -1.740145 & 0.0857 \\
\hline $\mathrm{D}(\mathrm{INF}(-4))$ & $-0.003528 * *$ & 0.001586 & -2.224506 & 0.0289 \\
\hline $\operatorname{ASIECM}(-1)$ & $-0.071414 *$ & 0.024126 & -2.960000 & 0.0040 \\
\hline R-squared & 0.647762 & \multicolumn{2}{|c|}{ Mean dependent var } & 0.053375 \\
\hline Adjusted R-squared & 0.572483 & \multicolumn{2}{|c|}{ S.D. dependent var } & 0.128754 \\
\hline S.E. of regression & 0.105979 & \multicolumn{2}{|c|}{ Akaike info criterion } & -1.568222 \\
\hline Sum squared resid & 0.898528 & \multicolumn{2}{|c|}{ Schwarz criterion } & -1.294711 \\
\hline Log likelihood & 80.98908 & \multicolumn{2}{|c|}{ F-statistic } & 9.283793 \\
\hline Durbin-Watson stat & 2.063871 & \multicolumn{2}{|c|}{ Prob(F-statistic) } & 0.000006 \\
\hline
\end{tabular}

Source: Computed by the author

Table 5 recorded a substantial improvement over table 4.5 in the sense that the coefficient of determination or the adjusted $\mathrm{R}^{2}$ indicates that about $57.25 \%$ variability of the all share index in the Nigerian capital market can be explained by inflation, lending rate, foreign exchange rate and real output. The DW statistic in our output is 2.064 and is indicative that there is no serial correlation. With the F-value $9.284(\mathrm{p}<0.000006)$ for the regression, we reject the nulland accept that the regression is significant overall.

Hypothesis Two:

Ho:There is no significant relationship between the selected macroeconomic variables and market capitalization.

Table6. Parsimonious error correction result

\begin{tabular}{|c|c|c|c|c|}
\hline \multicolumn{5}{|c|}{ Dependent Variable: D(LNMKC) } \\
\hline \multicolumn{5}{|l|}{ Method: Least Squares } \\
\hline \multicolumn{5}{|c|}{ Date: 07/14/12 Time: $21: 52$} \\
\hline \multicolumn{5}{|c|}{ Sample(adjusted): 1987:2 2009:4 } \\
\hline \multicolumn{5}{|c|}{ Included observations: 91 after adjusting endpoints } \\
\hline Variable & Coefficient & Std. Error & t-Statistic & Prob. \\
\hline $\mathrm{C}$ & 0.006016 & 0.003896 & 1.544114 & 0.1266 \\
\hline D(LNMKC(-1)) & $1.837456^{*}$ & 0.091991 & 19.97437 & 0.0000 \\
\hline D(LNPLR(-1)) & $-0.198050 * *$ & 0.098231 & -2.016163 & 0.0472 \\
\hline D(LNGDP(-2)) & $0.052977 * *$ & 0.107890 & 2.639523 & 0.0412 \\
\hline $\mathrm{D}(\mathrm{INF}(-3))$ & -0.000470 & 0.000300 & -1.568040 & 0.1209 \\
\hline D(LNFEX(-3)) & -0.017957 & 0.012958 & -1.385776 & 0.1698 \\
\hline MKCECM(-1) & $-0.017277^{*}$ & 0.005856 & -2.950400 & 0.0042 \\
\hline R-squared & 0.954635 & \multicolumn{2}{|c|}{ Mean dependent var } & 0.075708 \\
\hline Adjusted R-squared & 0.947655 & \multicolumn{2}{|c|}{ S.D. dependent var } & 0.087723 \\
\hline S.E. of regression & 0.020070 & \multicolumn{2}{|c|}{ Akaike info criterion } & -4.847618 \\
\hline Sum squared resid & 0.031419 & \multicolumn{2}{|c|}{ Schwarz criterion } & -4.488924 \\
\hline Log likelihood & 233.5666 & \multicolumn{2}{|c|}{ F-statistic } & 136.7811 \\
\hline Durbin-Watson stat & 2.018412 & \multicolumn{2}{|c|}{ Prob(F-statistic) } & 0.000000 \\
\hline
\end{tabular}

Source: Computed by the author 
Table 6 showed that the coefficient of determination or the adjusted $\mathrm{R}^{2}$ indicates that about $94.77 \%$ variability of the market capitalization in the Nigerian capital market can be explained by inflation, lending rate, foreign exchange rate and real output. The DW statistic in our output is 2.018 and is indicative that there is no serial correlation. With the F-value 136.781 $(\mathrm{p}<0.000000)$ for the regression, we reject the null and accept that the regression is significant overall.

\section{EMPIRICAL RESULTS AND DISCUSSION}

With the existence of a cointegrating relationship among the variables established, the parsimonious error correction models for the relationship are estimated. The parameters, estimate along with the standard errors, t-values and the corresponding critical values are given in the tables. The results presented in table 5 could not yield any interesting insight into the determination of the performance of the stock market in Nigeria.

In order to derive a more policy oriented model, the insignificant variables and their lags were eliminated in a stepwise manner one after the other, paying special attention to the Schwarz criterion and the Akaike information criterion as well as the standard error regression in the elimination process.

In those tables, the individual variables show different effects on the Nigerian capital market. For example, real GDP, a proxy for general income level showthe expected positive coefficientsin both cases. But while it is significant at $1 \%$ level in the measurement of all-share index, it is significant at $5 \%$ level in measuring market capitalization. A one percent increase in general level of income will increase all-share index and market capitalization by $0.62 \%$ and $5.3 \%$ respectively. An increase in income level will enhance the demand for both consumption and investment, including investment in the stock market. Chen, Roll and Ross (1986) findings based on a US stock portfolio, indicated that future growth in economic activities was a significant factor in explaining stock returns. This finding is consistent with Maku and Atanda (2009) who observed that the NSE all-share index is consistently determined by real output. Thus, higher income will lead to better stock performance in Nigeria.

Prime lending rate showed the expected negative relationship in both cases. But while it is significant at $1 \%$ level in measuring all-share index, it shows a $5 \%$ significant level in measuring market capitalization. The result shows that lending rate is inversely related to the performance of the capital market. This finding is consistent with Maysami, Howe and Hamzah (2004) in Singapore, Bulmash and Trivoli (1991) in the United States, and Maysami and Koh (2000) in Singapore all observed a negative relationship between lending rate and the stock market. The reason is probably that an increase in lending rate increases the cost of production, which in turn causes lower cash flows, profit and dividend. Long-term interest rate serves as a better proxy for the nominal risk-free component used in the discount rate in stock valuation models and may also serve as a surrogate for expected inflation in the discount rate.

Inflation, a measure of macroeconomic instability, is in accordance with apriori expectation. It shows the expected negative coefficient. But while it is significant at $5 \%$ in measuring all-share index, itis statistically insignificant in measuring market capitalization. Fama (1977), Geske and Roll (1983), Chen, Roll and Ross (1986) and Mukherjee and Naka (1995) all suggested a negative relation between inflation and stock returns. Defina (1991) argued that rising inflation initially has negative impact on corporate income due to immediate rising costs and slowly adjusting output prices, reducing profits and therefore share prices. Macroeconomic instability increases uncertainty and risk investment and hence leads to negative impact on the stock market performance. Nonetheless, as price stability is one of the macroeconomic policy objectives of the Nigerian government and also an expected target of the Nigerian citizen, it is believed that the effect of inflation on stock performance will be insignificant.

Surprisingly, foreign exchange rate is not statistically significant at all. However, it has a negative sign in both cases. Mukherjee and Naka (1995) suggested a positive correlation between stock market returns and changes in the exchange rates. Their finding is contrary to the result of this study which shows an insignificant negative relationship. A possible explanation to this might be that the domestic economy adjusts to currency developments to reflect the impact of foreign income arising from exports measured in domestic currency over the short-run. Additionally, Government of Japan (1993) pointed out that the boom in the economy during the late 1980s has been driven by domestic demand rather than exports. Since high economic activity translates to an improved performance in the stock 
market, it implies that foreign exchange rate depreciation does not increase the average stock price. A stronger domestic currency will enhance the stock market in Nigeria.

\section{CONCLUSION AND RECOMMENDATIONS}

\subsection{Conclusion}

Many studies have been conducted to explore the variations of the capital markets to macroeconomic variables theoretically and empirically. The results of these studies vary greatly regarding the effect of changes in macroeconomic variables on stock returns. The main objective of this study is to explain the effect of the four selected macroeconomic variables including: inflation, prime lending rate, foreign exchange rate and real gross domestic product on the performance of the capital market in Nigeria using quarterly time series data from the first quarter of 1986 to the last quarter of 2009.

Our findings show that the selected macroeconomic variables have long-run significant effect on the performance of the Nigerian capital market and this is consistent with other empirical studies carried out earlier. In particular, our study show that the NSE all-share index is consistently determined by inflation, lending rate and real output during 1986 to 2009, while market capitalization is determined by inflation and real gross domestic product. In both cases, foreign exchange rate is not significant in determining the performance of the capital market. Investors should therefore pay particular attention to variables such as inflation, lending rate and real gross domestic product in their investment decisions rather than to the foreign exchange rate of the naira to one US dollar.

\subsection{Recommendations}

On the basis of the findings of this study, the following policy recommendations are made.

- To formulate active and flexible monetary policies to check unfavorable developments in the market as they arise.

- The Federal government should continue to pay particular attention to price stability as one of the key macroeconomic policy objectives in order to curb inflation.

- The government should continue to provide better macroeconomic environment for the private sector to lead the economy on a path of sustainable growth and development.

- In order to reduce inflationary expectations, government should promote policy transparency. Transparency tends to lower inflationary expectations by providing an implicit commitment mechanism on the part of the Central Bank. This makes the policy to become more credible and the public can form expectations that are closer to the policy targets.

\section{REFERENCES}

[1] Adam, A. M. \&Tweneboah, G. (2008). Do macroeconomic variables play any role in the stock market movement in Ghana? MPRA working paper no. 9368.

[2] Amadi, S. N., Onyema, J. I. \& T. D. Odubo (2002). Macroeconomic variables and stock prices: A multivariate analysis. African Journal of Development studies, 2(1), 159-164.

[3] Chen, N.F., Roll, R. \& Ross, S. (1986). Economic forces and the stock market. Journal of Business, 59, 383-403.

[4] Chong, C. S. \&Koh, K. L. (2003). Linkages of economic activity, stock prices and monetary policy: the case of Malaysia. Journal of Economic Studies, 14, 8-17

[5] Fama, E. F. (1970). Efficient capital markets: A Review of theory and empirical work. Journal of Finance, 25 (2), 383-417.

[6] Flannery, M. I \& Protopapadakis, A. A. (2002). Macroeconomic factors do influence aggregate stock returns. Review of Financial Studies, 15(3), 751-789.

[7] Foley, B. J. (1991). Capital markets. Hong-Kong: Macmillan.

[8] Ibrahim, M. H. \& Aziz, H. (2003). Macroeconomic variables and the Malaysian equity market: A view through rolling sub-samples. Journal of Economic Studies, 30, 6-27.

[9] Jaffe, J. \&Mandelkar, G. (1976). The Fisher effect for risky assets: An Empirical investigation. Journal of Finance, 31, 447-456. 
[10] Maku, O. E. \&Atanda, A. A. (2009). Do macroeconomic indicators exert shock on the Nigerian capital market? MPRA, 17,9-17.

[11] Nelson, C. R. (1976). Inflation and rates of return on common stock. Journal of Finance, 31(2), 471-483.

[12] Nwokoma, N. I. (2002). Stock market performance and macroeconomic indicators Nexus Nigeria: An empirical investigation. Nigerian Journal of Economic and Social Studies, 4, 4-26.

[13] Ologunde, A. O., Elumilade, D. O. \&Asaolu, T.O. (2006). Stock market capitalization and interest rate in Nigeria: A time series analysis. International Research Journal of Finance and Economics, 4,20-26.

[14] Pratten, C. (1993). The stock market. Cambridge: Syndicate press.

[15] Reilly, F. \& Brown, K. (1999). Investment analysis and portfolio management ( $7^{\text {th }}$ ed.) Chicago: Dryden press.

[16] Ross, S. A. (1976). The Arbitrage theory of capital asset pricing. Journal of Economic Theory, $13,341-360$.

[17] Serkan, Y. (2008). Macroeconomic variables, firm characteristics and stock returns: Evidence from Turkey. International Research Journal of Finance and Economics, 16, 1-6. 